\title{
Christoph Michels, Peter Franz Mittag (eds.), Jenseits des Narrativs. Antoninus Pius in den nicht-literarischen Quellen, Franz Steiner Verlag, Stuttgart 2017, ill. b/w, pp. 336, ISBN 978-3-515-11650-3
}

Certain periods in the history of Rome do not attract a great deal of attention from scholars. There may be various reasons for this. One of the most common is a lack of sources. Another might be these periods' lack of dynamism, meaning that any interest on them tends to result from the need to consider them in a historical narrative rather than any conviction that they are worthy of particular interest. Antoninus Pius' reign is generally considered to be one such period. His long rule, free from any major political conflicts or large-scale military campaigns, was auspicious for his subjects, yet for scholars it was a time of stagnation. A manifest example of the lack of any great interest in the time of his rule is the fact that W. Hüttl's monograph (Antoninus Pius. Historisch-politische Darstellung, vols. 2, Prague 1933-36), published over 80 years ago, continues to be its fullest illustration. The general lack of interest in this period is further conditioned by the limited number of available of, essentially rather general, written sources. What we do have, however, is a considerable and steadily growing pool of epigraphic, numismatic and iconographic evidence which to date has not fully been exploited in research on Antoninus' rule. The need for a systematic analysis of these sources therefore seems rather obvious, but not until Christoph Michelis and Peter Franz Mittag's conference "Jenseits der Narrativs - Antoninus Pius in den nicht-literarischen Quellen", held in Aachen in September 2014, was any notable attempt made in this direction. The main idea of the conference was defined as follows: "[...] die literarische Tradition mit der archäologischen, numismatischen, papyrologischen und epigraphischen Evidenz zu kontrastieren", in order to paint a picture of Antoninus Pius' rule independent from that gleaned from written sources. The papers presented at the conference have now been published.

Findings concerning the various aspects of Antoninus' rule are given in 13 articles written by 12 authors. Some are more general, whereas others examine specific issues from the perspective of the various types of sources. The participants particularly focused on two of these: numismatic and iconographic evidence. Numismatic sources, owing to the legends and types of reverses, allow us to view the propaganda contents of both imperial and municipal minting. Because of its state-wide circulation, the former type offered the emperor an important outlet for exerting influence through propaganda upon various groups of the empire's inhabitants, depending on the denomination of the particular issues (cf. S. Börner, Von Pietas und Krisen-Antoninus Pius im Spiegel seiner stadtrömischen Münzprägung, pp. 109-129). An especially interesting type of numismatic sources, whose issue during Antoninus Pius assumed considerable dimensions, was imperial medallions (cf. P. F. Mittag, Zu einigen ungewöhnlichen Medaillons des 
Antoninus Pius, pp. 131-149). These had few recipients, and the images presented in them are therefore worthy of close attention. The iconography of their reverses is substantially different from that on the reverses of coins, and this, given the more personal nature of medallions, ensures a better understanding of the emperor's worldview and values system (cf. p. 146). Municipal minting was very popular in the Greek-speaking provinces of the Roman Empire. Since it reflects both the general trends of the imperial policy and local events, cultural traditions, religious life, as well as social life, it provides a considerably greater insight into the question of the perception of Antoninus Pius and his policies by his subjects in the provinces. The authors of written sources either do not provide such a perspective, or treat these issues only very superficially. Owing to the diversity of the information contained in municipal minting, the subject of the content of the minting of the cities of Roman Anatolia can be found in P. Weiß's two articles (Das Bild von Antoninus' Pius in den städtischen Münzprägungen des Ostens, pp. 151-180; id., Euergeten und Elemente der Zweiten Sophistik in der Münzprägung von Asia unter Antoninus Pius, pp. 181-194). The various aspects of the presentation of Antoninus as emperor in Rome's official art, minting and literature are presented in several texts (G. Seelentag, Antoninus Pius und die Herrschaftsdarstellung des 2. Jhs., pp. 19-30; D. Boschung, Jenseits des Narrativs? Kaiserporträt und Staatsrelief in der Zeit des Antoninus Pius, pp. 53-63; M. Haake, Image-Politik. Antoninus Pius, 'Greeks under Rome', und das kaiserliche Image zwischen Erwartungshaltungen und Selbstdarstellung - skizzenhaft exemplarische Überlegungen, pp. 195-213; C. Michels, 'Bilder' des Verhältnisses von Princeps und Provinz zur Zeit des Antoninus Pius, pp. 229-253).

Apart from those already mentioned, the volume also contains articles describing Antoninus Pius' activity as ruler in areas that are not irrelevant to the evaluation of his rule as a whole. These included D. Palombi's article Antoninus Pius and Rome: sobrius, parcus, parum largiens, pp. 65-87. The author analyses sources concerning Antoninus' construction works within Rome. By verifying all the sources containing references to this field of his activity, he arrives at the conclusion that not all the buildings attributed to the emperor were in fact his work, as he only completed them. Another important article is that of W. Eck (Die Städte des Reiches und ihr kaiserlicher 'Euerget': Antoninus Pius' Politik gegenüber den Gemeinden des Imperium, pp. 215-228), which tests the opinion that the emperor was a benefactor of various cities. There is no evidence to confirm that this was the case. This lack of munificence notwithstanding, Antoninus also pursued a policy of restrained bestowal of Roman citizenship. In his relations with provincial cities, he strove to limit the number of costly legations sent by them to Rome. An efficient way of doing this was the practice of obligatory mediation of the provincial governors. Without their approval, no legation from the provinces could go to Rome. Governors also played an important role in contacts between the capital and the peripheries, i.e. between the imperial chancellery and provincial cities. The governors received packets containing imperial correspondence, forwarding the individual letters to their addressees.

According to common opinion, which has mostly been shaped by the writings of ancient authors, Antoninus Pius' policies as ruler did not emphasise military and martial affairs. Michael M. Speidel's article Antoninus Pius, das Militär und der Krieg. Epigraphische Korekturen zur literarischen Überlieferung (pp. 255-268) puts this view to the 
test on the basis of epigraphic sources. The author finds that it is not only unjustified, but that sources demonstrate that there were numerous and relentless conflicts which required the emperor's action and continual attention. These conflicts are known from Britain, Germany, Upper Dacia, the Black Sea basin and Mauretania. The author suggests that the reason why Antoninus Pius did not place adequate emphasis on promoting his military successes and endeavours may have resulted from his following the example of Numa Pompilius, a peace-loving ruler of Rome with whom he was compared not only by contemporary writers, but by Roman historians too. This identification was also popularised by the actions of the emperor himself, carried out together with Marcus Aurelius (cf. 267-268).

Using sources from outside the narrative canon made it possible to illustrate Antoninus Pius' rule from a different perspective. Although this does not diverge markedly from the familiar version, it does add new significant elements to the profile of his rule that suggest that the previous assessment of Antoninus' time as emperor may require revision. Analysis of non-literary sources paints a picture of a ruler with a distinct ideological programme for his rule. One sign of this was his changing attitude towards his predecessor: from demanding that the senate enact posthumous honours for Hadrian as a condition of his assumption of power to discreetly and systematically overshadowing him by promotion the members of his own family: his wife Faustina the Elder, as well as his future successor Marcus Aurelius and his wife Faustina the Younger (J. Fündling, Anima anceps. Bewertung und dynastische Funktion Hadrians zwischen 138 und 180, pp. 31-51; S. Priwitzer, Antoninus Pius, die beiden Faustinen und die Ehe, pp. 89-108; Börner, op. cit.). As ruler, he was able to create an original model of propaganda which, despite the lack of slogans referring to military successes and the loyalty of the army, assured him stability of his rule. Non-literary sources also show that Antoninus Pius' time as emperor was characterised by the implementation of a number of decisions which, although perhaps not significant reforms, were favourable to the interests of the empire and made its administration more efficient. There is no doubt that the conference organisers were successful in achieving their objective. The publication presents an image of a ruler that is substantially different from that seen in the previous literature. It encourages not only reading of the texts it contains, but also further studies on Antoninus Pius' rule. One drawback is the repetition in the book of certain problems in at least several texts. Yet this is an inevitable consequence of a volume containing conference papers, particularly as their authors use the same sources.

Edward Dąbrowa (Jagiellonian University in Kraków) 